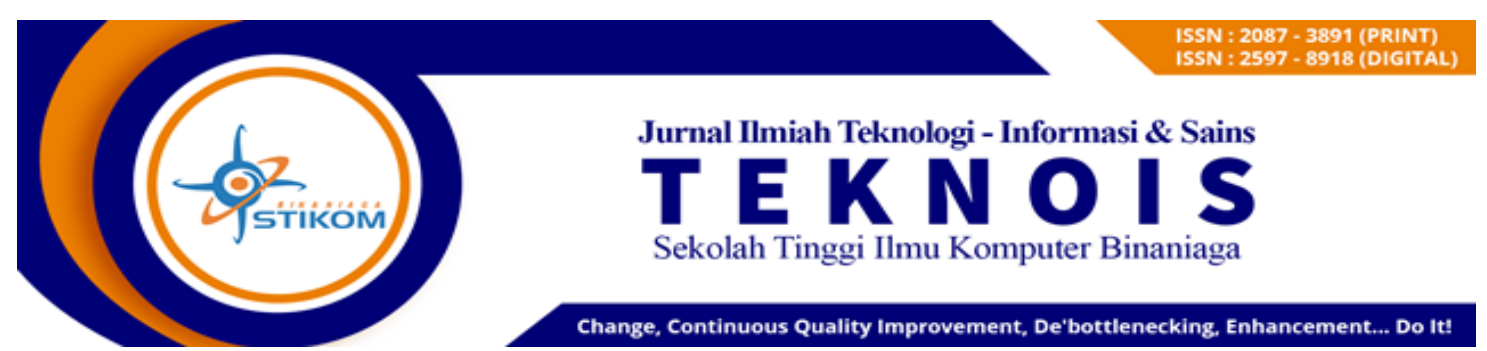

Received: September; Accepted : October; Published : October

\title{
Determination of value price or computer application using function point analysis method
}

\author{
Didik Suwito Pribadi \\ Teknik Komputer dan Informatika/Politeknik Negeri Bandung \\ Email: didik,pribadipolban@gmail.com
}

\begin{abstract}
Some developer very capable to develop good quality working applications, but they don't have the right value and price for their product, and it is because they did not use the right methods to calculate the size of the product and valuate them correctly most of the user analogy and expert judgment to perform their product sizing and valuation. This situation will create inconsistensi in doing the pricing and will create disadvantages both for developer and user. Function point analysis provides a methodology to perform software size calculation using algorithmic approaches that gives comprehensive and consistent results. In ithis document, I will explain step by step the process of calculating Function point using FPA procedures using EI, EO, EQ, ILF, EIF, and VAP. I also will implement them to calculate the size of XIbar application system especially module customer care and customer info.by doing all these activities I hope will provide a simple template and procedure calculating the size of application software that can be used easily by a developer, student, and others who need it.
\end{abstract}

Keywords: app calculation, application price, applicayions FP size, apps size calculation using FPA.

\section{A. INTRODUCTION}

\section{Background}

Many developers have developed computer applications that are well-running, and have been used by users. The application has been equipped with the functionality needed by the user, with the latest technology available. But when asked about how much value or price from the application developed and how the value is obtained, there is no definite and consistent answer. This happens because they do not calculate prices properly and correctly, most of them determine the selling price or the price of the application they developed with intuition or analogy or expert judgment, so the prices they set are inconsistent, sometimes too cheap sometimes too high should. If this condition continues, it will have a negative effect on the world of computer application development in this country, both for developers and users. To overcome the above problems, a more comprehensive method of pricing computer applications must be used that is algorithmic and consistent, and repeatable. There are several methods of algorithmic calculation such as function point analysis (FPA), constructive cost modeling (COCOMO), line of code (LOC), etc. The above methods have long been used to determine the basic value/price of computer applications in a good and consistent manner. 
However, to be able to use calculations using the above method, one must have knowledge of the techniques and methods and have the skills to use or apply the method properly and correctly.

Based on the above considerations, the authors compiled a paper related to the method or application calculation technique using the function point analysis method. This paper is expected to obtain a comprehensive description of how to calculate the value of an application with the FPA method that is easy to understand and can be implemented.

\section{The Problem}

Problems to be conveyed in this scientific work are:

a. What stages are used in the process of calculating application values using the FPA method?

b. How to implement the FPA method to determine the selling price of an application that has been developed?

\section{Purpose}

The purpose of this paper is to explain the stages of the FPA method and implement the method in the process of calculating the value and determining the selling price of a computer application.

\section{Literature Review}

a. Function point analysis techniques and approaches.

The technique and the function point analysis (FPA) approach proposed by Albrecht is referred to as the Function Points metric. This metric is obtained from the basic connection between the software information domain and software complexity. To get the software size, the Function Point analysis method uses a function-oriented approach by measuring the functionality and features of the application to estimate the size of the software. The results of the base price estimation are then used to estimate the total development costs and business costs needed to develop the system.

1) Determination of the number of function points (unadjusted).

The FPA component includes two main components namely data and transactions broken down into five basic subcomponents namely input data known as External input (EI), output data known as external output (EO), External Inquiry (EQ), internal logical file (EIF)), and external interface file (EIF).

in the calculation process is determined based on Data Element Type (DET), which is a data field or data item, which is not repeated, in an ILF. Example: Customer Code, and File Type Reference (FTR), which is a file designated as a reference by the transaction. An FTR must be an ILF or EIF) for the EI, EO and EQ domains. Whereas the ILF and EIF domains are calculated based on DET and RET (Record Element Type, subgroups of data in a logical file. Example: a customer).

Then calculate the project's Unadjusted Function Point (UFP) value by adding up the ILF, EIF, EI, EO, EQ function points. then calculate the determine function point (DFP) by multiplying by the value of the adjustment factor and the coefficient specified.

2) Calculation of Value adjustment factor (VAF).

In the FPA method, the Value Adjustment factor is a factor that must be taken into account because it can significantly influence the value of the application being built, which includes technology, additional features applied to the application being built. 
To calculate the value adjustment point (VAP) FP values are used which are obtained from the answers contained in the questions on the element adjustment factor (AF). The list of question categories for determining VAPs from FPAs that are adapted from the alvinalexander.com page is as follows:
a) How many data communication facilities are there?
b) How are distributed data and processing functions handled?
c) Was response time or throughput required by the user?
d) How heavily used is the current hardware platform?
e) How frequently are transactions executed?
f) What percentage of the information is entered on-line?
g) Was the application designed for end-user efficiency?
h) How many internal logical files are updated by the on-line transactions?
i) Does the application have extensive logical or math processing?
j) Was the application developed to meet one or many user needs?
k) How difficult are conversion and installation?
1) How effective / automated are startup, backup, and recovery?
$\mathrm{m})$ Was the application designed for multiple sites/organizations?
n) Was the application designed to facilitate change?

3) Calculation of the determined function point value

Known as DFP is calculated using the following formula:

$\mathrm{DFP}=$ unadjusted FP $\mathrm{x}(0.65+0.1 \mathrm{x} \mathrm{VAP})$

The next DFP amount is used as the basis for further price calculation.

b. Xibar customer information system application

The "XIBAR" customer information system application of PT Ibar Sistem Solusi that will be reviewed consists of new connection modules, meter reading, billing, collection, debt right-off, customer care, and customer info. The scope of the study in this paper will cover customer care and customer info only. The function details for the above modules are as follows:

1) Costumer Care

The list of functions of the customer care module application is as follows:

Table 1. List of function of the customer care module

\begin{tabular}{|c|l|l|}
\hline No. & Fuction Name & \multicolumn{1}{|c|}{ Description } \\
\hline 1. & $\begin{array}{l}\text { New } \\
\text { Subscription } \\
\text { Connection } \\
\text { Installation }\end{array}$ & $\begin{array}{l}\text { Is a feature to handle the registration of prospective } \\
\text { customers and the connection of meters to prospective } \\
\text { customers, so that they are registered as customers }\end{array}$ \\
\hline 2. & $\begin{array}{l}\text { Subscription } \\
\text { Termination (at } \\
\text { customer's } \\
\text { request) }\end{array}$ & $\begin{array}{l}\text { Termination of the Subscription at the request of the } \\
\text { customer is a feature that provides service to the customer } \\
\text { to terminate the connection at its own request to } \\
\text { unsubscribe }\end{array}$ \\
\hline 3. & Subscription & Recording of Termination of Connection is an application \\
\hline
\end{tabular}




\begin{tabular}{|c|l|l|}
\hline & $\begin{array}{l}\text { Termination } \\
\text { (due to arrears) }\end{array}$ & $\begin{array}{l}\text { used to handle the process of recording customers who will } \\
\text { be subjected to the process of terminating the meter } \\
\text { connection. Customers who enter this list are only } \\
\text { customers with the type of "sealed" news. }\end{array}$ \\
\hline 4. & $\begin{array}{l}\text { Changes in } \\
\text { Customer Data } \\
\text { Corrections and } \\
\text { Movements) }\end{array}$ & $\begin{array}{l}\text { Changes in Customer Data (Corrections) Is a process to } \\
\text { handle the correction/editing of customer data. } \\
\text { Change of Customer Data (Mutation) This is a process to } \\
\text { handle the replacement of a customer's water meter } \\
\text { ownership by another customer. }\end{array}$ \\
\hline 5. & Change meter & $\begin{array}{l}\text { It is a process to handle meter replacement because of } \\
\text { damage/meter leak / other things that require meter } \\
\text { replacement to be done. }\end{array}$ \\
\hline 6. & Tariff Correction & $\begin{array}{l}\text { It is a feature to replace customer data correction/editing, } \\
\text { especially tariffs. }\end{array}$ \\
\hline 7. & Fix unplug stand & $\begin{array}{l}\text { Unplug correction is an application that is used to handle } \\
\text { the customer registration process that will be corrected by } \\
\text { the meter stand when the water meter is changed, a booth } \\
\text { entry error occurs. }\end{array}$ \\
\hline
\end{tabular}

2) Costumer Info

Table 2. list of customer info module functions

\begin{tabular}{|l|l|l|}
\hline No. & Fuction Name & \multicolumn{1}{c|}{ Description } \\
\hline 1. & $\begin{array}{l}\text { Customer } \\
\text { information and } \\
\text { historical data }\end{array}$ & $\begin{array}{l}\text { Is a function that provides detailed customer information } \\
\text { and historical data (concerning the process of changing } \\
\text { data, for example changing meters, changing names etc.). }\end{array}$ \\
\hline 2. & $\begin{array}{l}\text { Account } \\
\text { Information }\end{array}$ & $\begin{array}{l}\text { It is a function that can be used to search for customer } \\
\text { account information. Search can be done based on SL } \\
\text { number, name, address, etc. Besides displaying account } \\
\text { information on this function, it also displays historical } \\
\text { information on customer usage. }\end{array}$ \\
\hline 3. & $\begin{array}{l}\text { Account } \\
\text { Simulation }\end{array}$ & $\begin{array}{l}\text { It is a function to simulate account counts with input } \\
\text { parameters; etc }\end{array}$ \\
\hline 4. & Fee Information & $\begin{array}{l}\text { It is a function to display cost information related to new sl } \\
\text { pairs, change data requests (change meters, change names, } \\
\text { etc.). }\end{array}$ \\
\hline 5. & $\begin{array}{l}\text { Customer } \\
\text { Complaints }\end{array}$ & $\begin{array}{l}\text { It is a function that displays information and status of } \\
\text { complaints from both customers and non-customers. } \\
\text { Complaints can be received through the help desk or via } \\
\text { SMS). }\end{array}$ \\
\hline 6. & SMS Bill Info & $\begin{array}{l}\text { It is a function that provides billing information to } \\
\text { customers according to the registered mobile number. The } \\
\text { information displayed is account billing information } \\
\text { (current + arrears) and other bills (eg fines) }\end{array}$ \\
\hline
\end{tabular}

\section{B. METHOD}


In carrying out this activity several steps or processes will be carried out to obtain the value or selling price of the application. The steps are as follows:

\section{IDENTIFICATION OF FUNCTIONS AND FEATURES OF THE APPLICATION MODULE TESTED.}

a. Feature identification; At this stage, an analysis of the functions in the application module is carried out to obtain the number of functions in the application being reviewed

b. Feature identification; Identify what features are available in each application function

2. CALCULATE DET, FTR, AND RET EVERY FEATURE.

The next step is to identify the number of data element types (DET) and file type references (FTR) for each feature. Determining the DET value is done by calculating the data component items involved and used in the feature, while the FTR value is calculated using the number of files used on the feature. Then it is used to calculate the FP of each feature

3. CALCULATE THE AMOUNT OF UNADJUSTED FUNCTION POINT (UFP) EVERY FUNCTION

a. Calculate the function points of each application feature.

1) Based on the DET and FTR values obtained in step 1, the number of function points (FP) of the EI, EO, EQ, ILF, ILF, EIF for each feature is then calculated using the category table.

2) FP values for each feature obtained by adding FP values without EI, EO, EQ, ILF, and EIF.

3) After the total number of FPs per feature is obtained, then summed to produce the total number of FPs that will form the total number of FP functions.

b. Add the value of the function point into the FP module.

After all the modules studied were added up, a UFP was obtained for the modules studied.

4. CALCULATE VALUE ADJUSTMENT POINT (VAP).

Calculate the FP value for each of the value adjustment factor (VAF) categories, which consists of 14 factors thickened with general system characteristics (GSC). Next, add the FP values to the 14 factors to get a VAP value that represents the Total Degree of Influence (TDI)

5. CALCULATE DETERMINED FUNCTION POINT (DFP)

After UFP and VAP are obtained, DFP calculations are then performed using the specified formula.

6. CAlCUlate THE SALE VALUE.

After the DFP value is obtained, it is necessary to set a development price per FP, which will be used to calculate the value or final price of the application. To determine the sale value, the amount of DFP is multiplied by the tariff per FP plus development costs.

\section{RESULT AND DISCUSSION}

\section{RESULT}

\section{a. Determination of Application Features}

The application features are made up to the smallest application unit level, represented by the smallest UI. 
1) The results of identifying the application features for all functions in the customer care module can be seen in the following table:

Table 3. Function and features of customer care applications

\begin{tabular}{|c|c|}
\hline \multicolumn{2}{|c|}{ Nama fungsi dan fitur aplikasi customer care } \\
\hline 1. Pemasangan Sambungan Baru (SB) & 2. Penggantian Meter \\
\hline Pendaftaran SB (Tambah) & Entri Pendaftaran Penggantian Meter \\
\hline Pendaftaran SB (Edit) & Edit Pendaftaran Penggantian Meter \\
\hline Pendaftaran SB (Hapus) & Hapus Pendaftaran Penggantian Meter \\
\hline Entri PK Survey Calon Pelanggan & Entri Data SPK Penggantian Meter \\
\hline Hapus PK Survey Calon Pelanggan & Hapus SPK Penggantian Meter \\
\hline Entri BA Survey Calon Pelanggan & Entri BA Penggantian Meter \\
\hline Edit BA Survey Calon Pelanggan & Edit BA Penggantian Meter \\
\hline Hapus BA Survey Calon Pelanggan & Hapus BA Penggantian Meter \\
\hline Entri SPK Penyambungan Baru & Pengesahan Penggantian Meter \\
\hline Hapus SPK Penyambungan Baru & Pelaporan Penggantian Meter \\
\hline Entri BA Penyambungan Baru & 3. Angsuran \\
\hline Edit BA Penyambungan Baru & $\begin{array}{l}\text { Pembuatan BA Angsuran } \\
\text { Penyambungan Baru }\end{array}$ \\
\hline Hapus BA Penyambungan Baru & $\begin{array}{l}\text { Pembuatan BA Angsuran } \\
\text { Penyambungan Kembali }\end{array}$ \\
\hline Pengesahan Penyambungan Baru & Pembuatan BA Angsuran Tunggakan \\
\hline Pengesahan Kolektif Penyambungan Baru & Edit Data Angsuran \\
\hline Pelaporan - Sambungan Baru & Hapus Data Angsuran \\
\hline 4. Penyesuaian Golongan Tarif & Laporan Detil BA Angsuran \\
\hline Entri Pendaftaran Penyesuaian Tarif & 5. Pindah Taping \\
\hline Edit Pendaftaran Penyesuaian Tarif & $\begin{array}{l}\text { Entri Pendaftaran Permintaan Pindah } \\
\text { Taping }\end{array}$ \\
\hline Hapus Pendaftaran Penyesuaian Tarif & $\begin{array}{l}\text { Edit Pendaftaran Permintaan Pindah } \\
\text { Taping }\end{array}$ \\
\hline Pengesahan Penyesuaian Tarif & $\begin{array}{l}\text { Hapus Pendaftaran Permintaan Pindah } \\
\text { Taping }\end{array}$ \\
\hline Pelaporan Penyesuaian Tarif & Entri Data SPK Pindah Taping \\
\hline $\begin{array}{l}\text { 6. Pemutusan Sambungan Atas Permintaan } \\
\text { Pelanggan }\end{array}$ & Hapus SPK Pindah Taping \\
\hline $\begin{array}{l}\text { Entri Pendaftaran Permintaan Pemutusan } \\
\text { Sambungan }\end{array}$ & Entri BA Pindah Taping \\
\hline $\begin{array}{l}\text { Edit Pendaftaran Permintaan Pemutusan } \\
\text { Sambungan }\end{array}$ & Edit Data BA Pindah Taping \\
\hline $\begin{array}{l}\text { Hapus Pendaftaran Permintaan Pemutusan } \\
\text { Sambungan }\end{array}$ & Hapus BA Pindah Taping \\
\hline Entri Data SPK Pemutusan Sambungan & Pengesahan Pindah Taping \\
\hline Hapus SPK Pemutusan Sambungan & Pelaporan Pindah Taping \\
\hline Entri BA Pemutusan Sambungan & 7. Pelayanan Armada Tangki \\
\hline Edit Data BA Pemutusan Sambungan & Pemesanan Air Tangki \\
\hline
\end{tabular}

(C)2019 Teknois : Jurnal Ilmiah Teknologi Informasi dan Sains. Copyrights All rights reserved 


\begin{tabular}{|c|c|}
\hline Hapus BA Pemutusan Sambungan & Tambah Pemesanan Air Tangki \\
\hline Pengesahan Pemutusan Sambungan & Edit Pemesanan Air Tangki \\
\hline Pelaporan Pemutusan Sambungan & Edit Pemesanan Air Tangki \\
\hline 8. Penyambungan Kembali & Laporan Detil Pemesanan Air Tangki \\
\hline Entri daftar Penyambungan Kembali & Laporan Rekap Pemesanan \\
\hline Edit daftar Penyambungan Kembali & Disposisi Air Tangki \\
\hline Hapus pendaftaran Penyambungan Kembali & Tambah Disposisi Air Tangki \\
\hline Entri SPK Penyambungan Kembali & Edit Disposisi Air Tangki \\
\hline Hapus SPK Penyambungan Kembali & Hapus Disposisi Air Tangki \\
\hline Entri BA Penyambungan Kembali & Laporan Detil Disposisi Air Tangki \\
\hline Edit BA Penyambungan Kembali & Laporan Rekap Disposisi \\
\hline Hapus BA Penyambungan Kembali & Surat Pengantan Pengirimain Air \\
\hline Pengesahan Penyambungan Kembali & Bukti Pengambilan Air \\
\hline Pelaporan Penyambungan Kembali & Pelunasan Air Tangki \\
\hline 9. Perubahan Balik Nama & $\begin{array}{l}\text { Laporan Detil Pengisian dan Pengiriman } \\
\text { Air Tangki }\end{array}$ \\
\hline Entri Pendaftaran Perubahan Balik Nama & $\begin{array}{l}\text { Laporan Rekap Pengisian dan } \\
\text { Pengiriman Air Tangki }\end{array}$ \\
\hline Edit Pendaftaran Perubahan Balik Nama & 10. Pelayanan Tera Meter Pelanggan \\
\hline Hapus Pendaftaran Perubahan Balik Nama & Entri Pendaftaran Tera Meter \\
\hline Pengesahan Perubahan Balik Nama & Edit Pendaftaran Tera Meter \\
\hline Pelaporan Perubahan Balik Nama & Hapus Pendaftaran Tera Meter \\
\hline 11. Koreksi Data Pelanggan & Entri Data SPK Tera Meter \\
\hline Entri Pendaftaran Koreksi Data Pelanggan & Hapus SPK Tera Meter \\
\hline Edit Pendaftaran Koreksi Data Pelanggan & Entri BA Tera Meter \\
\hline Hapus Pendaftaran Koreksi Data Pelanggan & Edit Data BA Tera Meter \\
\hline Pengesahan Koreksi Data Pelanggan & Hapus BA Tera Meter \\
\hline Pelaporan Koreksi Data Pelanggan & Pelaporan Tera Meter \\
\hline \multicolumn{2}{|l|}{ 12. Pengaduan Pelanggan } \\
\hline \multicolumn{2}{|l|}{ Entri Pendaftaran Pengaduan } \\
\hline \multicolumn{2}{|l|}{ Edit Pendaftaran Pengaduan } \\
\hline \multicolumn{2}{|l|}{ Hapus Pendaftaran Pengaduan } \\
\hline \multicolumn{2}{|l|}{ Disposisi Pengaduan } \\
\hline \multicolumn{2}{|l|}{ Penyelesaian Pengaduan } \\
\hline \multicolumn{2}{|l|}{ Closing Pengaduan } \\
\hline Pelaporan Pengaduan & \\
\hline
\end{tabular}

2) The results of identifying application features for all functions in the customer info module can be seen in the following table:

Table 4. Functions and features of customer care applications

\section{Nama fungsi dan fitur aplikasi customer Info}

\section{Form Utama}

C2019 Teknois : Jurnal Ilmiah Teknologi Informasi dan Sains. Copyrights All rights reserved 


\begin{tabular}{|ll|}
\hline 2. & Informasi Pelanggan \\
\hline 1) & Informasi Pelanggan \\
\hline 2) & Cari Pelanggan \\
\hline 3) & Detil Pelanggan \\
\hline 4) & Cetak Rekening \\
\hline 5) & Cetak Stan \\
\hline 6) & Detil Lunas \\
\hline 7) & Detil Rekening \\
\hline 8) & Detil Angsuran \\
\hline 3. & Simulasi Rekening \\
\hline 9) & Simulasi Rekening \\
\hline 10) Hitung \\
\hline 4. & Informasi Pelayanan \\
\hline 11) Informasi Pelayanan \\
\hline 12) Lihat Status Pelanggan \\
\hline 13) View detil Status Pelayanan \\
\hline 14) Pengaduan Baru \\
\hline 15) Monitoring Pengaduan \\
\hline
\end{tabular}

\section{b. Calculation of the UFP Amount of application features}

The results of the calculation of the number of UFP functions of customer care applications and customer info obtained as many as 3479 FP, with details can be seen in the following table:

Table 5. FP Table customer care applications

\begin{tabular}{|l|c|}
\hline \multicolumn{1}{|c|}{ Fungsi Aplikasi customer care } & UFP Total \\
\hline 1. Form Utama & 24 \\
\hline 2. Pemasangan Sambungan Baru (SB) & 495 \\
\hline 3. Penyesuaian Golongan Tarif & 138 \\
\hline 4. Pemutusan Sambungan Atas Permintaan Pelanggan & 298 \\
\hline 5. Penyambungan Kembali & 313 \\
\hline 6. Perubahan Balik Nama & 140 \\
\hline 7. Koreksi Data Pelanggan & 136 \\
\hline 8. Penggantian Meter & 291 \\
\hline 9. Angsuran & 168 \\
\hline 10. Pindah Taping & 288 \\
\hline 11. Pelayanan Armada Tangki & 431 \\
\hline 12. Pelayanan Tera Meter Pelanggan & 253 \\
\hline 13. Pengaduan Pelanggan & 172 \\
\hline \multicolumn{2}{r}{ Total UFP customer care } \\
\hline
\end{tabular}


Table 6. UFP customer care table

\begin{tabular}{|c|c|}
\hline Fungsi Aplikasi customer info & UFPTotal \\
\hline 1. Form Utama & 24 \\
\hline 2. Informasi Pelanggan & 185 \\
\hline 3. Simulasi Rekening & 24 \\
\hline 4. Informasi Pelayanan & 99 \\
\hline Total FP customer info & 332 \\
\hline
\end{tabular}

\section{c. Calculation of the number of VAP applications}

VAP calculation is performed on the whole application system, meaning that the VAP calculation is done after the total UFP for the entire application package is obtained. The results of the calculation of the number of VAP applications obtained a total degree of influence (TDI) of 49, which states the level of general system's characteristics (GSC) in the high category. Details of TDI results can be seen in the following table

Table 7. List of calculated VAF and FP components

\begin{tabular}{|l|c|}
\hline Komponen adusment Factor & score \\
\hline 1) How many data communication facilities are there? & 3 \\
\hline 2) How are distributed data and processing functions handled? & 3 \\
\hline 3) Was response time or throughput required by the user? & 2 \\
\hline 4) How heavily used is the current hardware platform? & 4 \\
\hline 5) How frequently are transactions executed? & 3 \\
\hline 6) What percentage of the information is entered on-line? & 5 \\
\hline 7) Was the application designed for end-user efficiency? & 3 \\
\hline 8) How many internal logical files are updated by on-line transaction? & 5 \\
\hline 9) Does the application have extensive logical or math processing? & 2 \\
\hline 10) Was the application developed to meet one or many user needs? & 4 \\
\hline 11) How difficult is conversion and installation? & 4 \\
\hline 12) How effective/automated are startup, backup, and recovery? & 4 \\
\hline 13) Was the application designed for multiple sites/organizations? & 4 \\
\hline 14) Was the application designed to facilitate change? & 3 \\
\hline Total & 49 \\
\hline
\end{tabular}

\section{d. Calculation of the number of DFP applications}

DFP count calculation for each application function using the following:

$$
\text { DFP = unadjusted FP } x(0.65+0.1 \times \text { VAP })
$$

By entering the number of UFP and VAP that have been calculated, the calculation results are as follows:

$$
\begin{gathered}
\mathrm{DFP}=\mathbf{3 4 7 9} \times(0.65+0.01 \times \mathbf{4 9}), \\
\mathrm{DFP}=\mathbf{3 9 6 6} \mathrm{FP}
\end{gathered}
$$


Thus the total value of the function point of the customer care module and the Customer info Xibar application system is 3966 Function Points.

\section{e. Calculation of the value or price of the application}

The value or price of the application calculated is determined by the number of DFP and development costs per FP, a component of the organization's management costs.

As an illustration, development costs are $\$ 90$ per hour, with a productivity level of 14 hours per FP (Harris, Pam, total metrics). For the Indonesian region, the hourly development cost will be assumed to be 40 thousand rupiahs. Organizational management costs including management, marketing, licensing fees, etc. will be incurred from the application fee to be determined according to the developer's organization policy.

Simply put the value or price of the application is calculated using the following formula:

Selling price $=$ DFP $x$ Dev cost

Selling price $=3966 \times(14$ hours $*$ Rp. 40000)

Selling price $=3966 \times(14 \times 40000)=\operatorname{Rp} 2,220,960,000$

\section{DISCUSSION}

a. VAP implementation should be applied to all application systems. Because in this activity the calculation is performed on just one module, the VAP price is applied to only one module. This results in a lack of accuracy of the value or price obtained (too large). So if you do a thorough calculation of all Xibar application modules, the application of VAP must be adjusted, by applying the VAP once for the total DFP value.

For the results of calculating the DFP value or price the customer care module can be described as follows:

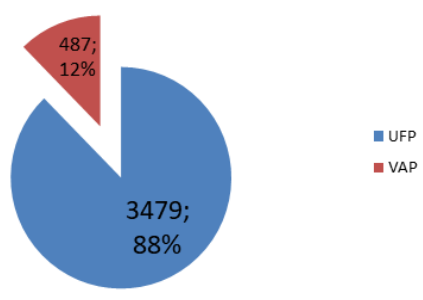

Figure 1. Composition of UFP and VAP

b. Determination of development costs adjusted to local conditions. In this case, it is assumed to be Rp. 40000 / hour 


\section{CONCLUSION}

1. The calculation of FP values is based on the functions and features of the application. So the determination of functions and features with care and detail is needed because it will affect the amount of FP obtained. For applications with large databases and the complex determination of DET and FTR is tricky, because in the existing process not all data elements are used. So the determination of DET for the EI and EO data components must be careful.

2. VAP determination must be thorough and careful because it can significantly influence the final results. The VAP value should be calculated for the entire application package intact, whereas in this case the VAP is applied to the application module partially so that the final FP value obtained affects the accuracy of the calculated price.

3. For the Xibar Customer Care System application module, a total Function Point of 3588 FP is obtained. Assuming an hourly development fee of Rp. 40000, and productivity for 14 hours per Function Point, the final value or value of the customer service module is Rp2,220,960,000 (two billion, twenty million rupiah, nine hundred and sixty thousand rupiahs), excluding the management costs of the developer's organization.

4. In this study, the composition of the percentage of UFP and VAP were as follows: UF 18\% and VAP $12 \%$.

5. The advantage of FPA is that measurements are carried out from the perspective of the user, are technologically independent, inexpensive, repeatable, and work well with use cases.

\section{E. REFERENCES}

[1] Alexander, Alvin j, 'How to Determine Your Software Application Size Using Function Point Analysis', tersedia di http://www.Alvinalexander.com, diakses tanggal 10 juli 2019.

[2] IBARSIS, 'XIBAR software metric and development cost', system documentation, Jakarta , 2017.

[3] Khatibi, Vahid. dan Jawawi, Dayang N. A., 'Software Cost Estimation Methods: A Review', Journal of Emerging Trends in Computing and Information Sciences, Vol 2, no1 ,p 21-26, 2011.

[4] Pam Morris, "Measuring the size of the software product from the perspective of what gets delivered to the user", Total Metrics Australia, WWW.Totalmetrics.com , 2019 